\title{
To be or Not to be Authentic. In Defence of Authenticity as an Ethical Ideal
}

\author{
Katharina Bauer ${ }^{1}$ (D)
}

Accepted: 16 March 2017 / Published online: 28 March 2017

(C) The Author(s) 2017. This article is published with open access at Springerlink.com

\begin{abstract}
It has recently been pointed out that the cloudiness of the concept of authenticity as well as inflated ideologies of the 'true self' provide good reasons to criticize theories and ideals of authenticity. Nevertheless, there are also good reasons to defend an ethical ideal of authenticity, not least because of its critical and oppositional force, which is directed against experiences of self-abandonment and self-alienation. I will argue for an elaborated ethical ideal of authenticity: the ambitious ideal of a continuous self-reflective process of 'self-authentication'. For this purpose, the ideal of being authentic in expressing and unfolding one's individual personality and characteristics will be combined with the ideal of being 'an authentic person' - whereby 'a person' is to be understood in a Kantian sense as an autonomous person who is (at least potentially) reasonable and morally responsible.
\end{abstract}

Keywords Authenticity · Autonomy $\cdot$ Person $\cdot$ Responsibility for one's self

\section{1 "To Thine Own Self be True" (Hamlet, Act I, Scene 3)?}

Recently, philosophical theories based on an ethical ideal or a character-based ideal of authenticity have harshly been criticized for two reasons. First, it has been stated that philosophy is "unable to harness authenticity in a fully satisfying way" (Bialystok 2014, 259). Authenticity is suspected to be a vague, ambivalent, and overcharged concept that is not an adequate subject of serious philosophical debate but, rather, an intrinsically psychological issue or simply a commonplace description of personality. Second, the modern ideal of 'being authentic' is criticized as a pop-cultural fad - an element of a self-help ideology that becomes most obvious in Oprah Winfrey's "love-your-self-first self-esteem boosterism" (Feldman 2015, 3). Feldman's recent attack in "Against Authenticity" is directed against an individualist

Katharina Bauer

k.bauer@ rug.nl

1 Faculteit Wijsbegeerte, Ethiek, Sociale en Politieke Filosofie, Rijksuniversiteit Groningen, Oude Boteringestraat 52, 9712 GL Groningen, Nederland 
ideology of being true to the self you want to be-whoever you want to be, be it a good or bad, moral or immoral person. But can we really imagine that authenticity-in particular if it is interpreted explicitly as an ethical ideal—would be attributed to an 'authentic serial killer' or to an 'authentically brutal and rigid dictator'?

It is the aim of this paper to develop an ethical ideal of being an authentic person, which is much more elaborated than its pop-cultural equivalent. I will try to avoid a mere selfish orientation of the ideal as well as complete moral neutrality or an exaggerated moralization. In order to contribute to the task of harnessing authenticity in a more satisfying philosophical manner, I will proceed as follows: After introducing and comparing different accounts and ideals of authenticity in section 2, I will deal with the question of which ideas about being authentic as well as about being a person come into play when an ideal of authenticity is ascribed to a concrete person (section 3). This will be clarified with the aid of an example (the authentic vs inauthentic dictator) and discussed against the background of debates about the relationship between personal authenticity and moral responsibility.

Finally (in section 4), I will argue for an ideal of being an authentic person who performs a continuous self-reflective procedure of 'self-authentication'. This ethical ideal of authenticity will incorporate the ideal of an authentic unfolding and expression of one's individual personality as well as the ideal of being authentic in being 'a person', whereby 'a person' will be understood in a Kantian sense as an autonomous person who is (at least potentially) reasonable and morally responsible.

\section{2 'Be Who You Want to be' - a Selfish Ideal?}

In his attack in "Against Authenticity", Simon Feldman argues very committedly against the ideal of being true to yourself. He points out that only a good and reasonable person should be true to herself, meanwhile it would be morally better if an authentically bad person would be untrue to her true self or even become someone else: "It can be morally best to lack selfknowledge - or even to live in bad faith - when the alternatives lead us to harm others, in accordance with our 'true' and perhaps vicious or simply amoral selves" (Feldman 2015, 15).

Furthermore, Feldman argues against authenticity as a selfish ideal that requests to "love-your-self-first" (see above). Overemphasis and degenerations of ideals of authenticity, individuality, and self-fulfilment related to "neo-Nietzschean aestheticism or atomistic selfindulgence" (Varga 2012, 28) have been criticised as the "malaises of modernity" $(1992,1)$. However, Charles Taylor, who raises this criticism, still tries to defend authenticity as an ethical ideal, which exceeds the paradigm of instrumental reason and even "opens an age of responsibilization" (77). An ethical ideal of authenticity "tries to give answers to the question of how to lead a good life" (Varga 2012, 5). Such an ideal can serve as a personal standard. However sometimes the activity of aiming at an ideal - as well as activities of aiming at a virtue or trying to realize the standards of a moral theory - can rather be counterproductive (cf. Arpaly 2002 and Stocker 1976, 461). And it is questionable in how far a personal ideal of authenticity can be directly action-guiding. It rather seems to be "good-making" (cf. Feldman 2015, 127 f.): if the ideal is met, it contributes to the quality of a person's life. The ideal of authenticity can thus be regarded as a standard of evaluating the quality of a person's life and of the person herself who leads her life more or less authentically. Taylor states that the wish for an authentic life is prima facie inseparable from the ideal of a good life. Completely narcissistic conceptions of personal authenticity are unthinkable to him, because persons and their individual 
personalities are always involved in and influenced by social relationships: "We define [our identity] always in dialogue with, sometimes in struggle against, the identities our significant others want to recognize in us" (33).

It should not be forgotten that the idea of a "struggle against" others played an important role within the historical development of the modern ideal of authenticity. From Rousseau's withdrawal from society to Sartre's mauvaise foie [bad faith] and Heidegger's Eigentlichkeit in opposition to das Man, the ideal of authenticity is related to resistance against the pressure to conform. A person can gain her authenticity by distancing herself from others. However, if authenticity is defined as being true to oneself, it is possible to imagine an authentic conformist - a person who is "disposed to conform" and who is only true to herself if she corresponds to social standards (Buss 2013, 1358). We can also imagine an authentic altruist or an authentic socially engaged person who is not a 'conformist' but authentically social. Such a person would not be authentic in distancing herself from others; rather, she is realizing her authenticity in the interaction with others.

The variety of imaginable persons who have been introduced thus far as candidates for being authentic persons (authentic egoists, nonconformists, conformists, altruists) hints at the problem of the openness and vagueness of the ideal of authenticity (cf. Bialystok 2014). What does it mean to be authentic? I would like to start from a preferably neutral definition: According to Somogy Varga, the ideal of authenticity "roughly" means, "that one should lead a life that is expressive of what a person takes herself to be" $(2011,113)$. Here, an epistemic account of authenticity that presupposes self-knowledge is combined with an account of authentic self-expression. To better grasp another important element of the current "standard account of authenticity" (Oshana 2007, 413) I would like to add to Varga's formula: "of what a person wants herself to be". According to such a volitional account of authenticity, which goes back to Harry Frankfurt, being true to yourself means being true to the commitments, plans, and objects of caring you wholeheartedly identify with. It means being true to the self 'you want to want to be' according to a second-order volition. Frankfurt presupposes that everyone wants to be 'a self', 'a unity', respectively a person, who constitutes and structures her own identity, and who is constantly and clearly identifiable. The volitional account of authenticity thus implies the goal of being a person. People can be "wantons" according to Frankfurt, who follow any of their impulses spontaneously and who cannot succeed to become a wellorganized unity. But persons necessarily structure their volitions; they organize them hierarchically, exclude some desires from their personality, decide which desires become action guiding, and they are able to identify wholeheartedly with their decisions. It is important that it is not the main intention of Frankfurt's theory of our volitional structure and of wholehearted identification to explain what it means to be authentic; rather, he wants to suggest what it means to be (identified as) a person.

Frankfurt intends to describe the structure of being a person without directly prescribing normative evaluations or ideals, e.g., of being a better or worse person. Susan Wolf attributes to him a "distaste for moralism" $(2002,241)$. The formation of a volitional unity is fundamental for being accountable for one's actions, but Frankfurt does not explicitly argue for a morally responsible self-formation or self-constitution as a good person. Morality is only important for a person in so far as it is an object of her personal caring (cf. Frankfurt 2002, 248). He points out "that immoral lives can be good to live" (ibid.). Essential conditions of a life that is good to live are the activities of loving and caring. The 'necessities of love' that follow from those activities generate imperatives for a person's actions, which have to be regarded as 'categorical', but they are explicitly not identical with Kant's moral categorical 
imperative (cf. Frankfurt 1998). Actually, the imperative of a volitional account of authenticity says: 'be who you want to (want to) be'. Meanwhile Kant's understanding of being an autonomous person implies the idea of giving oneself a law [nomos], which is the moral law. The self-imposed law that structures one's volitions primarily has to be successful in establishing the unity of the person. It does not have to correspond to external (moral) standards. Frankfurt's ideal of being an authentic person does not conform to the ideal of being an autonomous moral agent-'a person' in the Kantian sense. And authenticity is surely not primarily a 'moral' ideal. In the discourse of modernity, the ideal of acting authentically - in terms of acting according to one's character or personalityand of living an authentic life is rather brought into opposition against rigid ideas of morality. Can it be defended as an ethical ideal, which is neither morally dubious nor overly moralistic?

Even though the cloudiness of the concept of authenticity as well as inflated ideologies of the 'true self' provide good reasons to criticize theories and ideals of authenticity, there are also good reasons to defend a more elaborate ethical ideal of authenticity. It should not be understood primarily as a promise of individual wellbeing or self-fulfilment. Striving for an authentic life is surely not the one and only way that leads to a good life. The particular value of ideals of personal authenticity - in terms of acting and living in accordance with one's own self-understanding and with individual convictions, values, volitions or ground projectsinstead emerges from its power to serve as a defence against negative experiences of suppression and alienation. The ideal of acting authentically and of living an authentic life can be brought into opposition against antiquated role models (e.g., the devoted housewife) and against extreme ideals of self-control, thoughtfulness, and selflessness, with a tendency towards complete self-abandonment and self-alienation. How can this oppositional and critical force be supported without going to the other extreme of a merely individualist and narcissistic ideal of self-fulfilment? How can it be defended against the objection that the 'true self' could be a morally bad self and that inauthenticity sometimes seems to be the preferable ideal? I think this is possible, if the ideal of being an authentic person is not separated from a particular ideal of being 'a person' and if it is tied to the ideal of gaining self-knowledge and thinking critically about who one truly is and truly wants to be.

\section{3 'Just be Authentic' or 'be an Authentic Person'?}

To figure out what it means to argue for the ideal of 'being an authentic person', I would like to borrow an example from Susan Wolf. She introduces it in her reflections in "Sanity and the Metaphysics of Responsibility" to show that the "deep-self view fails to be convincing when it is offered as a complete account of the conditions of responsibility" (1987, 367). The deep-self view says "that if we are responsible agents, it is not just because our actions are within the control of our wills, but because, in addition, our wills are not just psychological states in us, but expressions of characters that come from us, or that at any rate are acknowledged and affirmed by us" (365). Wolf refers to Harry Frankfurt, Garry Watson, and Charles Taylor. Though she does not explicitly refer to Frankfurt's and Taylor's theories of authenticity, it seems obvious that the deep-self view is closely related to the idea of authenticity or, more precisely, to the idea of corresponding to your true self and of expressing it authentically. 
To challenge the deep-self view (and turn it into the 'sane deep-self view') Wolf introduces the following example:

Jojo, the son of an evil dictator, is raised up and educated to follow in his father's footsteps. He becomes a brutal dictator and totally endorses his role and his function, "including sending people to prison or to death or to torture chambers on the basis of whim" (365).

Wolf's description of the example is rather short. But it seems to be very similar to the NorthKorean dictator Kim-Jong Un. Wolf states that Jojo is not really responsible for his deeds. He is acting according to his deep-self, but he is also not 'sane': He probably knows what he is doing (first condition of sanity), but he cannot distinguish between right or wrong (second condition of sanity) due to the problematic genesis and formation of his deep-self (cf. 368). According to Wolf, it corresponds to our current pretheoretical intuitions to regard Jojo as insane and thus as not being fully responsible for his actions. Many people might agree that he should not be called on to account for his deeds. However, Shoemaker and Faraci have shown that experimental data does not confirm Wolf's assumption about our current pretheoretical intuitions (cf. Faraci and Shoemaker 2010). I think that there are not only strong intuitions, but also good reasons to deny that Jojo is insane. His education and indoctrination have not automatically destroyed his capacity of distinguishing between right and wrong and of taking a moral point of view or at least of considering different perspectives - which I regard as fundamental capacities of authentically being 'a person'. I will start from a volitional view of authenticity and amplify it step by step to examine if and how Jojo would be regarded as being authentic according to different accounts of authenticity. Thereby, I want to extrapolate which ideas about being authentic and about being a person have to be presupposed for ascribing authenticity as an elaborated ethical ideal to someone.

\subsection{The Volitional View of Authenticity}

According to a volitional view of authenticity, Jojo is authentic. Wolf underlines Jojo's wholehearted identification with his role and with his function as a dictator. If this wholehearted identification is the decisive aspect of authenticity-regardless of the question of whether the contents of the identification are self-authored or whether they are adopted from others or even the result of indoctrination-Jojo is true to the self he wants (to want to) be. And he is not a wanton, insofar as he does not solely act on the basis of whim. If we allow for a neutral, formal conception of authenticity (what the person takes herself to be or wants herself to be), there is no problem to describe Jojo's self-understanding, his actions, and his way of life as being authentic. Describing him as being 'authentic', however, does not automatically entail ascribing value to that description. Nevertheless, on closer examination, it is very difficult to separate any conception of personal authenticity from ethical evaluations related to ideals like strength of character, resistance against the pressure of conformism, sincerity, or truthfulness (cf. Trilling 1972). Following Trilling, the quest for individual authenticity as truthfulness towards oneself, which has replaced the older ideal of sincerity, serves as a substitute for the search for truth and for the striving for a life according to an eternal and universal idea of the good, or, to put it another way, it can be regarded as a substitute for the orientation towards a universal ideal of the virtuous self or 'the authentic person' as such. With Trilling, the career of the modern ideal of personal authenticity is a reaction to the transformation of a self that was 
well-integrated into social structures (though probably sometimes bound to those structures in a negative way) into a self that is much more self-directed, but does not feel at home and cannot find its place in the social world or in a higher order of the universe.

Jojo surely knows his place in his society. He probably would not feel the need to be acknowledged as an authentic person; rather, he would make sure that his people regard him as 'the true dictator' who embodies the truth of power. But if an external viewer described Jojo as being authentic, he probably would refer more or less explicitly to important values and ideals that are ascribed to authentic persons. This does not mean that those values are automatically regarded as overriding compared to other values and moral norms. One can imagine a clandestine admiration for Jojo's authenticity, for his wholehearted self-identification, for the clear and stable order of his volitions, as well as for his self-assuredness, which is still outreached by a strong disapproval of his immoral and anti-social comportment as a brutal dictator. So one could also imagine valuing him for being formally authentic without valuing what particular kind of person he is authentically - thus, without valuing the contents of his authentic self.

\subsection{An Account of 'Self-Authentication'}

The volitional account of self-constitution via wholehearted identification and structuring one's volitions usually presupposes a strong interrelation between authenticity and autonomy. Both concepts are based on the idea of a self-reference (autos) respective of something being self-generated. Authenticity and autonomy cannot be separated if generating one's own personality means giving it a 'law' (nomos), be it the moral law or the formal law of how to structure and order ones volitions. Both attributes - autonomy as well as authenticityunderline that it is the person herself who generates this law and originates the structure of her self. The combination of authenticity and autonomy is related to the ideal of being a 'selfmade' and 'self-governed' person. It refers to a value that is ascribed to the individual person and to her capacity to form her own personality, her identity, and to follow her own way of life in a self-directed manner. On that condition, it becomes more difficult to describe Jojo as being 'authentic'. He misses the aspects of originality and self-authentication. He rather seems to be 'originally self-alienated'. He is a kind of copy of his father. His role and comportment are given to him. He may identify with being 'Jojo the authentic dictator', but if he is not able to take a reflective distance towards his own role and personality and if he cannot imagine any alternative identity for himself, his identification seems to be too passive and too heteronomous to regard him as being actively 'self-authenticated'.

According to Frankfurt, it is autonomy that is "a matter of whether we are active rather than passive in our motives and choices" (Frankfurt 2006, 20). It implies a strong connotation of activity and self-control; meanwhile, authenticity can also refer to the passivity of being necessitated by ones volitions and being captivated by love. So Frankfurt would not necessarily have to regard Jojo as being less authentic than his father because of his passivity towards the formation of his identity. The original use of the term authenticity refers to the authenticity of a work of art or a document. Those authentic works are, of course, made by a particular author. They do not generate themselves. Nevertheless, being an authentic person implies a prominent connotation of an active self-formation and a choice of a personal way of life among different alternatives. Existentialist accounts of authenticity are based on a strong idea of self-authorship. Such accounts connect "authenticity to human freedom" - the freedom of an "agent that makes of herself who and what she is through her choices" (and with Sartre 
she has no other choice than to execute such freedom) (Drummond 2010, 453). Nevertheless, the kind of accountability that is linked to this idea of freedom neither amounts to the moral responsibility of an autonomous agent who explicitly takes responsibility for his actions as he reflects about their appropriateness to moral law, nor does it really satisfy another notion of responsibility: a dialogical structure of giving each other reasons in the practice of holding each other responsible. This is the understanding of responsibility that Charles Taylor seems to have in mind when he argues for a responsibilization of authenticity. Furthermore, he presupposes a responsibility for self (cf. Taylor 1976).

\subsection{Authenticity, Strong Evaluations, and 'Responsibility for Self'}

Susan Wolf underlines that Jojo cannot distinguish between right and wrong. In the limited horizon of his ideologically-restricted world there is just one unquestionable truth as well as one unquestionable identity for him. What does that mean for his characterization as an authentic or inauthentic person? Frankfurt presupposes that persons are characterized by "reflective self-evaluation that is manifested in the formation of second-order desires" (Frankfurt 1971, 7). Jojo has the second-order desire to be a successful and powerful dictator. He can probably distinguish between actions and events that are good or bad for him and for his aims as a dictator (e.g., what maintains or undermines his power). Still, to what degree is he really capable of a reflective self-evaluation? According to Charles Taylor, there is an important difference between "a strong evaluator", who "ascribes a value" to some of his desires, and "a simple weigher" (1976, 287 f.). The latter is "already reflective in a minimal sense" - which "is a necessary feature of what we call a self or a person" (ibid.). He can reflect about the strength of his different desires and about the best way to fulfil them. Nevertheless, the simple weigher lacks a certain 'depth', because he cannot articulate and communicate his evaluations or develop contrastive characterizations like good vs. bad. He may be able "to step back from the immediate situation" (ibid.), but he cannot really step back from his desires. He fails to reflect on "what these desires express and sustain in the way of modes of life" (288).

What about Jojo? As stated above, he is not a Frankfurtian wanton who follows all of his desires and impulses immediately without any self-reflection, self-control, or self-structuring. And as he wholeheartedly and deliberately identifies with his role and personality in Wolf's example, he also does not seem to be a simple weigher. He may be able to articulate and communicate strong evaluations according to the ideology of his dictatorship. Wolf's statement that he cannot distinguish between right and wrong does not mean that he is not able to articulate any contrastive evaluations. She intends to point out, rather, that he is not able to take a moral point of view or to use neutral and objective standards of judgement.

I think that Taylor implicitly presupposes two different levels of strong evaluation: reflective evaluation and self-reflective evaluation. Jojo is a strong evaluator in so far as he reflects on his evaluations and articulates them. Still, he lacks another important form of evaluation. He probably steps back from his desires and from the immediate situation. But he does not properly step back from himself - from his role and personality. Hence, he does not lack responsibility at all as Wolf presupposes, but he does not take any responsibility for (his own) self as Taylor conceives it. To be responsible for your own self means to be responsible for your actions, for acting in line with your evaluations, and "in some sense for these evaluations themselves" (289). And responsibility for the self essentially implies a possibility of reevaluation and of questioning one's own values and convictions: "Have I really understood what is essential to my identity? Have I truly determined what I sense to be the highest mode 
of life?" (296). I would like to stress that those two questions, which Taylor introduces to describe the procedures of a re-evaluation, can also be used to characterize the essential elements of a 'responsibilized' version of authenticity. They aim at a correspondence to one's own deep sense of self (i.e. What is essential to my identity? Am I true to my true self?), and they aim at a correspondence to an ideal of the good life and thus of 'the good self' (i.e. What do I sense to be the highest mode of life? Am I truthfully striving for the ideal of a good life?).

Jojo would probably not be ready to step back from his own identifications or to reevaluate. Instead, he would rather "refuse any radical questioning" (Taylor 1976, 298). Living in a closed horizon of a totalitarian regime maybe prevents him from adopting different perspectives, which would enable him to figure out alternatives of himself (cf. Bransen 2000). If so, he would not able to perform a radical and deep self-reflection: "it is a reflection about the self, its most fundamental issues, and a reflection which engages the self most wholly and deeply" (Taylor 1976, 299). This kind of strong evaluation and deep reflection about one's own identity and about the setting of one's convictions and evaluations makes us "responsible for ourselves" and this "is essential to our notion as a person" (ibid.). The ethical ideal of being an authentic person is strongly related to the idea of becoming aware of who you really want to be. This presupposes the capacity to step back from the present version of yourself and evaluate it in the light of the questions: Which person do you truly want to be? How do you really want to lead your life? However, this does not mean to presume implementing a universal standard of being 'the perfect authentic person' as such.

The account of authenticity that is most suitable with the idea of self-reflective evaluation is an epistemic account: Marina Oshana argues for such an "epistemic conception of authenticity offered by Karl Jaspers and taken up by Larry Man”, which basically defines authenticity as "truthfulness toward oneself and about oneself in word and deed" (Oshana 2007, 424). Thus, inauthenticity is characterized by dishonesty, self-deception, and a lack of integrity, which occurs because a person is not ready to accept parts of her life or history, in particular personal failures and indulgence. Oshana states that "one is inauthentic or lives inauthentically when one is not honest with oneself and, perhaps, others about one's position in the world and about one's ability to transform or even to take a stance with respect to that position" (425). The importance of a reference to 'the world' and one's position in it can be strengthened by a " "phenomenological' account of authenticity" that is based on the understanding of selfresponsibility in Husserl's ethics (Drummond 2010, 452). According to John Drummond, this account "connects authenticity to truthfulness, to having the proper sense of things" (453). The phenomenological alternative to the existential self-choice or "self-definition" is the idea "of self-realization insofar as I realize myself as a truthful and responsible agent" (453). Drummond emphasizes that Husserl's self-realization transcends the Aristotelian idea of a realization of natural predispositions insofar as it is most important for Husserl that human beings are able to make sense, which means to make moral sense and to establish structures of meaning and understanding. This corresponds to Susan Wolf's presupposition that human beings have an original "interest in truth" and an "interest in meaning" (Wolf 2002, 236). Against Frankfurt, she underlines that those interests also predefine the realm of possible objects that are worth caring about. A person cannot wholeheartedly identify with something opposed to those interests.

The idea of a 'self-responsibility' for an authentic unfolding of one's individual personality implies an obligation to develop one's talents and capacities and thereby contribute to the task of making sense by interpreting the world as truthfully as possible. A conception of authenticity as truthfulness towards oneself and towards 'the givenness of the world' is fundamentally 
interconnected with the idea of taking responsibility towards others for one's life, one's words, and one's deeds - that is, for one's self, as far as one is able to (re-)evaluate and modify one's comportment and one's characteristics. Even though persons are not able to 'make themselves' and to change or influence all of their natural dispositions and socio-cultural imprints, they are able to try to be truthful about themselves in their self-evaluations. And they are able to ask themselves whether they should stay true to the self they actually express in their actions and comportments or whether they rather want to become another version of themselves, which sometimes can be the "morally best" choice (see above). A self-critical epistemic form of personal authenticity is not only compatible with responsibility. It can even be regarded as an essential requirement of a responsible manner of dealing with one's own personality. Jojo obviously really lacks this kind of self-responsibility and self-critical authenticity.

\subsection{Being Authentic without Being a (Morally Responsible) Person?}

By implementing a universal standard of personhood, it is possible to describe Jojo as an authentic dictator, but also to deny that he is an authentic person because he fails to (fully) realize his capacity of being 'a person' both with regard to his self-constitution and with regard to his actions. This holds true if Taylor's responsibility for one's own self is regarded as an essential feature of being a person. And it also holds true if moral autonomy and an active selfconstitution as a moral agent are regarded as the fundamental functions of personhood (cf. Korsgaard 2009). Following a Kantian line of thought, persons are distinguished by their capacities to act as reasonable moral agents, to govern themselves, to establish their own normative principles, and to take a moral point of view.

Susan Wolf's Jojo, however, is characterized by an authentic incapacity to take any neutral or alternative point of view exceeding his personal dictator perspective. He is not able to step back from his convictions and habits. Does this serve as an excuse for being immoral? I have already underlined that it would probably be very demanding for Jojo to transgress the limited horizon of his worldview. It is possible that he has not learned anything about alternative ideals and values. And nobody else (no concrete other inside the system of his dictatorship) has the authority to call him to account for or to question his evaluations and his wholehearted identifications. Still, if Jojo - as a human being - is equipped with a general human ability to distinguish right from wrong, to take a moral point of view, and to act according to the moral law, this excuse is not satisfying. This also holds true if we do not share the strong Kantian claims about personhood, but still attribute a general capability to persons to transgress or widen their horizon, to consider different standards, to think about alternatives, and to take different points of view with regard to their actions, their evaluations, and their own identity. In particular, if Jojo is confronted with the people he mistreats - with their suffering and, perhaps, also with their protest against his tyranny - and if he puts himself into their position, this should prompt Jojo to start thinking differently. Actually, Susan Wolf holds that "although there is much in our characters that we did not choose to have, there is nothing irrational or objectionable in our characters that we are compelled to keep" (Wolf 1987, 370). She concludes: "although we may not be metaphysically responsible for ourselves - for after all we did not create ourselves from nothing - we are morally responsible for ourselves for we are able to understand and appreciate right and wrong, and to change our character and our actions accordingly" (371).

For Wolf, Jojo is not included in this 'we' as he is regarded as insane. She is right that he may not be able to generate distinctions between right and wrong apart from the distinction 
between what is good or bad for the fulfilment of his role as a dictator because of his very special experiences and education. But Jojo is not insane in a way that virtually makes him unable to learn how to understand the difference between right and wrong and thus to live and act in a morally responsible manner. As a potentially reasonable, moral, and adaptive person, he can be regarded as responsible for gathering information about alternative convictions, evaluations, and about examples for being a better sovereign of his state. He should transgress his horizon (and, as he is the dictator, one can imagine that he could actually open the borders of his country if they limit his horizon), even though this would be demanding. Following this line of thought, the procedure of self-authentication as an authentic person implies to take moral responsibility for one's life, one's words, and one's deeds as well as for the attempt at least to try to choose and realize the best alternative of one's self.

\section{Conclusion: An Elaborated Ideal of Being an Authentic Person}

It should be clear now that Jojo can be described as being authentic in a formal way (2.1), but at the same time, he does not correspond to important aspects of the ethical ideal of being an authentic person. He rather seems to be 'originally alienated' from this ideal. He misses the criterion of self-authentication (2.2), which presupposes the practice of reflective selfevaluation (2.3), and, on the assumption of a particular understanding of personhood, it is not even clear to what extent he can be regarded as a person, because he lacks an adequate moral self-reflection and self-evaluation (2.4).

Now, what is it that makes an authentic person? According to my previous argument, a necessary condition of being an authentic person is, in any event, a form of self-knowledge, or reflected self-evaluation. Recently there has been a debate about the question of whether the value of authenticity can be explained by appealing to the value of self-knowledge or whether it is possible to "explain the value of self-knowledge by appeal to the value of authenticity" (Feldman and Hazlett 2013, 158). Michael Lynch states that self-knowledge is valuable, because to know what you care about is important for being true to yourself, for one's authenticity, and, in the end, for one's happiness (cf. Lynch 2005, 127). I would rather argue that self-knowledge is not only important for being authentic, but also for being prudent, for acting efficiently, for giving reasons for one's actions or for being wise in a rather abstract philosophical sense. Furthermore, self-knowledge is not only valued because of instrumental benefits, but also as such. And if a person is valued for being authentic in terms of corresponding to an ethical ideal of authenticity she is usually also valued for having a certain degree of self-knowledge. There are other objections against Lynch's argumentation, in particular because "when it comes to spontaneity, the value of (that species of) authenticity conflicts with the value of self-knowledge" (Feldman and Hazlett 2013, 158). According to Lynch, a rather "simpleminded" character who "does not seem to think so much" (Lynch 2005, 123) can act very authentically, because he just knows what he cares about. Insofar as he knows what he cares about he knows himself.

I would like to stress that persons can find out and decide who they really are and who they really want to be in the very moment of an authentic self-expression, in which "we both discover and get in touch with who we are 'on the inside' and actively constitute (or 'produce') ourselves at the same time" (Varga 2012, 107). In situations of such existential choices, it is possible that "we take responsibility for who we are" (114). This can happen spontaneously or automatically, for example, in a moment of emergency in which a person just knows what to 
do without longer procedures of deliberation or without being really conscious about her motives (cf. Snow 2006). But the moment of such self-discovery and 'responsibilization' still presupposes certain procedures of truthful self-reflection about the self you are and the self you really want to be true to. The existential choice is based on procedures of self-examination that take place before the act of authentic self-expression, and it will bring forth procedures of selfreflection that take place after the act of explaining oneself and of giving reasons for one's authentic action in a responsible manner. Authentic actions that seem to be simply spontaneous often derive from internalized convictions, habits, and concerns. And authenticity as an ethical ideal is not reducible to spontaneous moments of self-expression.

Jeffrey Seidman has convincingly shown that "caring is, in part, a cognitive and deliberative disposition" (Seidman 2009, 301). What distinguishes mere desires from caring is the fact "that an agent who cares about some object will care about various ends focused around" that object and the agent will "exclude from her deliberation courses of action incompatible with that end" in a given deliberative context (314). Even if a simpleminded character "just knows' what he cares about, he has to deliberate more or less consciously about the course of action that does not conflict with the ends he cares about in the given situation. A person who authentically expresses herself in her actions gets to know herself — or at least the depth of her concerns - as she finds out which courses of actions are unthinkable or practically necessary for herself, because her caring "is a disposition to deliberate in certain ways" (320).

Furthermore, I would like to stress that the self-authentication of a person and the selfknowledge that is necessary for this procedure presuppose knowledge of the world -in particular of the social world - and of "intersubjectively intelligible values" (Varga 2015, 308). While Wolf defends the importance of our interest in truth and objective values for our wholehearted identifications, Varga points out that the core identifications that "really speak for us" and for our authentic personality "express both crucial volitional characteristics and central judgements about agent independent values" (ibid.). Re-authenticating your core self or reinvigorating your identification "when it starts to lose its motivating force" makes it necessary to "shift focus from volitional aspects to reasons that speak in favour of these identifications" (313). Being able to refer to such reasons is important to guarantee the continuity and effectiveness of one's own identifications towards oneself. And it is even more important if a person wants to be authentic in the eye of the other. Beyond her selfauthentication as an authentic personality, an authentic person also depends on being authenticated by others. The mutual authentication of persons as persons presupposes a realm of trustfulness as the individual self-authentication presupposes truthfulness about and toward oneself. Andre J. Pierce has recently argued for "a conception of authenticity based upon the intersubjective relation of trust", which shall, amongst other things, "reconcile authenticity with the moral demands of the social life" $(2015,436)$. This is a parallel account to Bernard Williams' reflections about authenticity (cf. Williams 2002, 172-205). For Williams, the quest for authenticity expresses the importance of the ideal of truthfulness, which is (as well as the virtues of sincerity and accuracy) essential for any social co-operation and for social institutions, because it allows the members of a society to trust each other. Social life is based on a mutual exchange of trust and truthfulness. In this respect, authenticity should also be defended as a social ideal. But this task goes beyond the scope of this paper.

So, let us get back to the core of authenticity as an ethical ideal and to the question of why and how authenticity should be regarded as normative feature that is inseparable from the ideal of being a person. Tim Henning offers an interesting argument with regard to "Kantian respect and Frankfurtian identification" (2011) that helps to answer this question more precisely. 
According to Henning the Kantian "idea that persons are ends in themselves" can and should lead us to the conclusion "that their desires and decisions deserve to be respected in a way which cannot be reduced to the first-order reasons which pertain to what they desire or decide to do" (744). In particular, in cases of conflicting desires it is required to figure out which desires of a person truly represent her will as this will ought to be respected (cf. ibid.). For this purpose, Henning suggests a priority of internal desires in the Frankfurtian sense, which can also be regarded as a priority of authentic self-identification or self-authentication. Indirectly, Henning gives a Kantian answer to Feldman's question of why being yourself should matter at all: because being yourself implies being a person and thus an end in itself. The account of self-authentication that I suggest is in alignment with Henning's account with regard to the ideal of respecting both the value of a person's original and individual desires and projects, as well as the dignity of her general status as a person in the Kantian sense. The different aspects of the ideal of authenticity that have been shaped from the interpretation of the Jojo example served to hint at the relevance of the ideal of expressing one's individual personality and of the ideal of being a person in the Kantian sense for understanding the ethical ideal of authenticity.

The implication of a traditional ideal of self-knowledge along with the ideal of authenticity has a particular ethical dimension insofar as gaining knowledge about one's individual authenticity and originality is not valued as an end in itself but as a means "to be better able to match the ideal that determines your function" (Guignon 2004, 8). To what kind of function should an authentic person be true to? Is it a universal function of being a moral agent and a good person? Does the account of authenticity that was introduced in this paper lead to the consequence that 'the true self' is identified with 'the good self' or with the 'morally good self'? According to Feldman, this identification makes Kantian-inspired theories of "authenticity as conscientiousness" so attractive, because it promises a solution to the motivational problem of morality, which is delusive from Feldman's point of view (Feldman 2015, 181): if it is a consensus that we have a strong desire to be true to ourselves and if being true to ourselves can be revealed as the equivalent to being (morally) good, we will be able to understand our desire for authenticity as the desire for moral righteousness. However, I argue for an ideal of a continuous process of self-authentication and not for the ideal of a clearly identifiable and unalterable true and good self. This self-authentication presupposes the capacities of moral judgment, of reasoning, of critical self-reflection, and of truthfulness - in terms of a sober and honest self-investigation - that allow for a flexible but responsible development of one's self. Conscientiousness is an important aspect of the ethical ideal of authenticity, and authenticity can be an important element of being a good person. But both aspects are not reducible to each other, because the complex and multidimensional ethical ideal of authenticity that comprises volitional self-identification, active self-authentication, responsibility for one's self, and the ideal of being an authentic person is not reducible to a mere moral ideal.

There are two functions of personhood, which are inseparable, if Christine Korsgaard is right that "the way to make yourself into an agent, a person, is to make yourself into a particular person, with a particular identity of your own" (Korsgaard 2009, 214). There is an important social function of a unique personality with individual talents and characteristics, as it contributes to the unfolding of a valuable social world, and there is a more general function of a person as a morally responsible agent for humanity, because it is essential for the possibility of any harmonious social interaction that human beings understand themselves as persons accordingly. 
I have introduced the ideal of being 'an authentic person' as a combination of the ideal of expressing and unfolding one's individual personality and the ideal of being an autonomous person who is morally responsible. An elaborated ideal of being an authentic person thus comprises of

\section{aspects of being authentic by being a self with distinctive characteristics of an individual} personality: a free unfolding of one's individual personality; expressing oneself in one's actions and one's way of life; a certain degree of self-authorship (though not selfcreation) or active self-constitution, which implies responsibility for one's own self; being true to one's own convictions, beliefs, ideals, life-plans, and projects; being truthful "toward oneself and about oneself in word and deed" (see above);

as well as,

aspects of being authentic by being 'a person' in terms of an autonomous (moral) agent: giving reasons for one's actions; being a strong evaluator as well as a 'reflective selfevaluator', who is able to re-evaluate who she really wants to be and to think about (better) alternatives of herself; taking moral responsibility for one's actions and for any active contribution to one's self-constitution; transgressing an exclusively personal perspective; being a trustworthy partner of social interaction.

It is important to underline that interpersonal authentication, as well as self-authentication, are not determining the authenticity of a person once and for all. We have to think about ongoing and highly-demanding procedures. The complexity of the procedures of self-authentication is enforced by the following fact, which was articulated by Sarah Buss: if a "person's capacity to call her commitments into question is also an important aspect of her identity" - and I have even suggested to understand this capacity as an important aspect of the identity of any person - "she cannot be true to herself without dissociating herself from these commitments" (2013, 1359). Does self-authentication imply a certain degree of self-alienation, because you have to distance yourself from yourself to find out who you really are, who you really want to be, and how to lead a life that is expressive of the person you want yourself to be? Is the only way to heal the "psychic rift" (1360), which can follow from such a dissociation, a way back into a more simple form of authenticity — of 'just being yourself' without self-examination? I agree with Buss' answer: "Abandoning our self-examination is [...] no more a way of being 'true to ourselves' than abandoning our substantive commitments. At best, it enables us to deceive ourselves into thinking that being true to ourselves is a simpler proposition than it really is" (ibid.). Feldman is surely right when he states: "self-critical thinking is no guarantee of thinking (morally) rightly" (Feldman 2015, 14). However, refusing any self-critical thinking is very often a guarantee of not thinking (morally) rightly, because it means to be bound to a narrow perspective, and it entails the risk of considering oneself to be the one and only true self. Furthermore, training one's capability of distancing oneself critically from one's own desires, dispositions, and identifications seems to be an important prerequisite of being able to reflect critically about one's role in society and about the validity of shared values and social and political orders (and borders). As stated above, an ability to resist uncritical conformity to problematic social standards and conventions is an important element in the historic development of the ideal of being an authentic person. Being true to one's self as a person is not simple at all—not as simple as 
the pop-culture discourse may suggest - and the elaborated ideal of being an authentic person is a very complex and demanding ideal. But perhaps that is just how our ethical ideals about ourselves should be. ${ }^{1}$

Open Access This article is distributed under the terms of the Creative Commons Attribution 4.0 International License (http://creativecommons.org/licenses/by/4.0/), which permits unrestricted use, distribution, and reproduction in any medium, provided you give appropriate credit to the original author(s) and the source, provide a link to the Creative Commons license, and indicate if changes were made.

\section{References}

Arpaly N (2002) Unprincipled virtue. An inquiry into moral Agency. Oxford University Press, Oxford

Bialystok L (2014) Authenticity and the limits of philosophy. Dialogue 53(2):271-298

Bransen J (2000) Alternatives of oneself. Recasting some of our practical problems. Philos Phenomenol Res LX 2:381-400

Buss S (2013) Accountability, integrity, authenticity, and self-legislation: reflections on Ruediger Bittner's reflections on autonomy. Erkenntnis 79:1351-1364

Drummond, J (2010) Self-responsibility and Eudaimonia. In: Ierna C, Jacobs H, Mattens F (eds.) Philosophy, phenomenology, sciences. Essays in Commemoration of Edmund Husserl, Springer, Dordrecht pp. 441-460

Faraci D, Shoemaker D (2010) Insanity, deep selves, and moral responsibility: the case of JoJo. Rev Philos Psychol 1(3):319-332

Feldman S (2015) Against authenticity: why you shouldn't be yourself. Lexington Books, Lanham

Feldman S, Hazlett A (2013) Authenticity and self-knowledge. Dialectica 67(2):157-181

Frankfurt H (1971) Freedom of the will and the concept of a person. J Philos 68:5-20

Frankfurt H (1998) Autonomy, necessity, and love. In: Necessity, volition, and love. Cambridge University Press, Cambridge, pp 129-141

Frankfurt H (2002) Reply to Susan Wolf. In: Buss S, Overton L (eds) Contours of agency: Essays on themes from Harry Frankfurt. MIT Press, Cambridge, pp 245-252

Frankfurt H (2006) The reasons of love. Princeton University Press, Princeton

Guignon C (2004) On being authentic. Routledge, London

Henning T (2011) Why be yourself? Kantian respect and Frankfurtian identification. Philos Q 61(245):725-745

Korsgaard C (2009) Self-constitution. Agency, identity, and integrity. Oxford University Press, Oxford

Lynch M (2005) True to life. Why truth matters. MIT Press, Cambridge

Oshana M (2007) Autonomy and the question of authenticity. Soc Theory Pract 33(3):411-429

Pierce A (2015) Authentic identities. Soc Theory Pract 41(3):435-457

Seidman J (2009) Caring and incapacity. Philos Stud 147:301-322

Snow N (2006) Habitual virtuous action and automaticity. Ethical Theory Moral Pract 9(5):545-561

Stocker M (1976) The schizophrenia of modern ethical theories. J Philos 73(14):453-466

Taylor C (1976) Responsibility for self. In: Oksenberg Rorty A (ed) The identities of persons. University of California Press, Berkeley and Los Angeles pp, pp 281-299

Taylor C (1992) The ethics of authenticity. Harvard University Press, Cambridge

Trilling L (1972) Sincerity and authenticity. Harvard University Press, Cambridge

Varga S (2011) The paradox of authenticity. Telos: Crit Theory Contemp 156:113-130

Varga S (2012) Authenticity as an ethical ideal. Routledge, New York

Varga S (2015) Core identifications: the motives that really "speak for us". Am Philos Q 42(4):301-317

Williams B (2002) Truth and truthfulness. An essay in Genealogy. Princeton University Press, Princeton

Wolf S (1987) Sanity and the metaphysics of responsibility. In: Schoeman F (ed) Responsibility, character, and the emotions: new essays in moral psychology. Cambridge University Press, Cambridge, pp 46-62

Wolf S (2002) The true, the good, and the lovable: Frankfurt's avoidance of objectivity. In: Buss S, Overton L (eds) Contours of Agency: Essays on themes from Harry Frankfurt. MIT Press, Cambridge, pp 227-244

\footnotetext{
${ }^{1}$ I would like to thank Pauline Kleingeld, Beate Rössler, Somogy Varga, Heidi Samuelson and particularly two anonymous reviewers for their insightful comments. They helped me to clarify my own contribution to the debate about authenticity and to make my paper more focused and substantial. I am also grateful to the Alexander von Humboldt foundation for supporting my work on this paper.
} 